\title{
A compact and stable eddy covariance set-up for methane measurements using off-axis integrated cavity output spectroscopy
}

\author{
D. M. D. Hendriks, A. J. Dolman, M. K. van der Molen, and J. van Huissteden \\ Vrije Universiteit Amsterdam, Faculty of Earth and Life Sciences Department of Hydrology and Geo-environmental Sciences \\ De Boelelaan 1085, 1081 HV Amsterdam, The Netherlands
}

Received: 12 July 2007 - Published in Atmos. Chem. Phys. Discuss.: 6 August 2007

Revised: 13 November 2007 - Accepted: 3 January 2008 - Published: 31 January 2008

\begin{abstract}
A Fast Methane Analyzer (FMA) is assessed for its applicability in a closed path eddy covariance field set-up in a peat meadow. The FMA uses off-axis integrated cavity output spectroscopy combined with a highly specific narrow band laser for the detection of $\mathrm{CH}_{4}$ and strongly reflective mirrors to obtain a laser path length of $2-20 \times 10^{3} \mathrm{~m}$. Statistical testing and a calibration experiment showed high precision $\left(7.8 \times 10^{-3} \mathrm{ppb}\right)$ and accuracy $(<0.30 \%)$ of the instrument, while no drift was observed. The instrument response time was determined to be $0.10 \mathrm{~s}$. In the field set-up, the FMA is attached to a scroll pump and combined with a 3-axis ultrasonic anemometer and an open path infrared gas analyzer for measurements of carbon dioxide and water vapour. The power-spectra and co-spectra of the instruments were satisfactory for $10 \mathrm{~Hz}$ sampling rates.
\end{abstract}

Due to erroneous measurements, spikes and periods of low turbulence the data series consisted for $26 \%$ of gaps. Observed $\mathrm{CH}_{4}$ fluxes consisted mainly of emission, showed a diurnal cycle, but were rather variable over. The average $\mathrm{CH}_{4}$ emission was $29.7 \mathrm{nmol} \mathrm{m}^{-2} \mathrm{~s}^{-1}$, while the typical maximum $\mathrm{CH}_{4}$ emission was approximately $80.0 \mathrm{nmol} \mathrm{m}^{-2} \mathrm{~s}^{-1}$ and the typical minimum flux was approximately $0.0 \mathrm{nmol} \mathrm{m}^{-2} \mathrm{~s}^{-1}$. The correspondence of the measurements with flux chamber measurements in the footprint was good and the observed $\mathrm{CH}_{4}$ emission rates were comparable with eddy covariance $\mathrm{CH}_{4}$ measurements in other peat areas.

Additionally, three measurement techniques with lower sampling frequencies were simulated, which might give the possibility to measure $\mathrm{CH}_{4}$ fluxes without an external pump and save energy. Disjunct eddy covariance appeared to be the most reliable substitute for $10 \mathrm{~Hz}$ eddy covariance, while relaxed eddy accumulation gave reliable estimates of the fluxes over periods in the order of days or weeks.

Correspondence to: D. M. D. Hendriks

(dimmie.hendriks@falw.vu.nl)

\section{Introduction}

Methane is the third most important greenhouse gas globally, after water vapour and carbon dioxide. Its concentration has risen by $150 \%$ since the pre-industrial era (Foster et al., 2007) and currently $20 \%$ of the enhanced greenhouse effect is considered to be due to methane (Foster et al., 2007). Although methane is less abundant in the atmosphere compared to carbon dioxide, it is a relatively strong greenhouse gas: the Global Warming Potential of methane expressed as $\mathrm{CO}_{2}$-equivalents is approximately 25 (over 100 years) while that of carbon dioxide is by definition 1 (Foster et al., 2007). For water vapour and carbon dioxide, the eddy covariance technique has been used for several decennia (Aubinet et al., 2000) to measure the exchange of these gases with the earth surface. In eddy covariance, the vertical flux $\left(F_{s}\right)$ of an atmospheric property $(s)$ is directly determined by the covariance of that property and the vertical velocity, as shown in Eq. (1). This can be obtained by calculating the time averaged product (over the period $t_{1}$ to $t_{2}$ ) of the deviation $\left(s^{\prime}\right)$ of the atmospheric property $(s)$, from $s=\bar{s}+s^{\prime}$, and the deviation $\left(w^{\prime}\right)$ of the vertical wind velocity $(w)$ from $w=\bar{w}+w^{\prime}$ :

$$
F_{s}=\overline{w^{\prime} s^{\prime}}=\frac{1}{t_{2}-t_{1}} \int_{t_{1}}^{t_{2}} w^{\prime}(t) s^{\prime}(t) d t
$$

(Aubinet et al., 2000). The eddy covariance technique requires an instrument with high precision, accuracy and system stability as well as high sampling rates and short instrument response time $(\tau)$. Unfortunately, the low abundance of methane in the atmosphere hampers adequate concentration measurements of this gas and the eddy covariance technique has therefore been rarely applied for the assessment of methane emissions (Kroon et al., 2007; Hargreaves et al., 2001; Kormann et al., 2001). The advantages of the eddy covariance technique compared to other techniques for measuring trace gases are nonetheless obvious: integrated continuous measurements over a large footprint area $\left(10^{2}\right.$ to $\left.10^{4} \mathrm{~m}^{2}\right)$

Published by Copernicus Publications on behalf of the European Geosciences Union. 


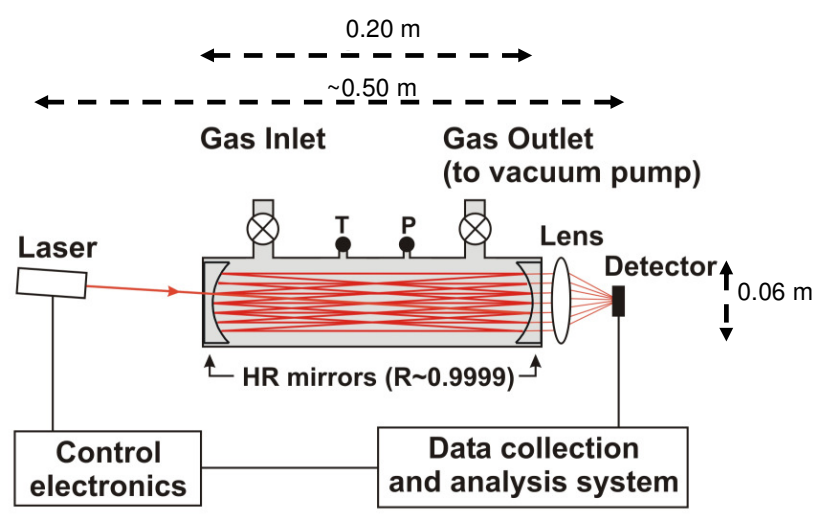

Fig. 1. Schematic overview of the integrated cavity output analysis (ICOS) technique used in the FMA. (Source: Los Gatos Research Ltd.) " $R$ " is the reflectivity of the mirrors and " $T$ " and " $P$ " are the sensors of $T_{\text {cell }}$ and $P_{\text {cell }}$.

and longer periods without disturbance from small scale surface features. These properties enable assessments of spatial and temporal variability at the landscape scale.

Since the 1980s, infrared absorption spectrometry using tunable diode lasers (TDLs) has been widely used for measurements of trace gases in the lab. A field technique for eddy covariance using a multipass absorption cell was introduced in 1995 (Zahniser et al., 1995). Unfortunately, serious problems of drift and low sensitivity effects occurred. Additionally, the method had more practical drawbacks: the large nitrogen Dewar for temperature control that needs refill weekly, an extensive and sensitive optical module, and frequent calibration. Improvements were made with the Quantum Cascade Laser (QCL) spectrometer which was first introduced in 1994 (Faist et al., 1994). The method was more stable and accurate in eddy covariance set-up than the TDL spectrometry (Nelson et al., 2004; Kroon et al., 2007), but the practical drawbacks of the methane instruments (large nitrogen Dewar, optical module, and frequent calibration) were still present in the QCL spectrometer technique. Hitherto, the micrometeorological measurement techniques for methane have thus implied very expensive, large and labour intensive field set-ups with logistic limitations to unattended field deployment.

The objective of this study was to investigate the applicability and quality of the FMA, a new off-axis integrated cavity output spectroscopy (ICOS) technique using a highly specific narrowband laser, for its applicability for eddy covariance field measurements of methane. The relatively userfriendly and low cost set-up is tested for precision, accuracy and system stability as well as its' performance in eddy covariance field set-up. The first data series are analysed and compared with data obtained by existing measurement techniques. To asses the applicability of the instrument at locations that lack external power supply, alternative measurements techniques of the set-up are simulated which could reduce the power requirements.

\section{Methods and materials}

\subsection{Instrument design}

A measurement cell with highly reflective mirrors was combined with a highly specific narrowband laser system by O'Keefe et al. (1998), creating a path length of at least two $\mathrm{km}$ in the measurement cell. In this manner, small absorption rates cause much larger reduction of the total transmitted laser intensity. The ICOS technique could therefore be used for the detection of gases with ultra weak absorption, while making the extensive optical module and the nitrogen Dewar superfluous. The operation of the DLT-100 Fast Methane Analyzer (FMA) from Los Gatos Research Ltd. is based on this improved ICOS technique and uses a distributed feedback (DFB) diode laser with a wavelength of nearly $1.65 \mu \mathrm{m}$. The DFB diode laser offers tunability, narrow line width and high output power in a compact and very rugged setup. It features a grating structure within the semi-conductor, which narrows the wavelength spectrum and guarantees single-frequency emission. Off-axis ICOS implies that a laser beam directed into the measurement cell at a slight angle, after which it is reflected in the cell numerous times by highly reflective mirrors (reflectivity $\sim 0.9999$ ), thus creating a path length of $2-20 \times 10^{3} \mathrm{~m}$ by making $1-10 \times 10^{4}$ passes in the cell (Bear et al., 2002; Fig. 1). The detector measures fractional absorption of light at the methane resonant wavelength, which is an absolute measurement of the methane concentration in the cell.

The path length of the laser, and therefore the time period during which the laser is being reflected in the cell for each measurement, is dependent on the reflectivity of the mirrors in the measurement cell. This period over which the laser is being reflected in the measurement cell is called the mirror ringdown time (MRT) and is continuously monitored by the FMA. The MRT cannot be allowed to drop below 3.0 to $3.5 \mu \mathrm{s}$, since the laser path length then becomes too short to detect the changes in laser intensity properly. The mirrors in the measurement cell are sensitive to dirt accumulating in the measurement cell; a small contamination of the measurement cell causes rapid decrease of the MRT. Cleaning the mirrors is a relatively simple procedure that can be done in a dust-free environment.

The FMA measures in the concentration range from 10 to $25 \times 10^{3} \mathrm{ppb}$ and operates autonomously. Technically, measurements can be made at rates up to $20 \mathrm{~Hz}$ and at ambient temperatures of $5{ }^{\circ} \mathrm{C}$ to $45^{\circ} \mathrm{C}$, while humidity should be below $95 \%$ to avoid condensation. The pressure in the measurement cell $\left(P_{\text {cell }}\right)$, which can be adjusted by a valve switch on the instrument, should be kept near $210 \mathrm{hPa}$. To obtain sampling rates higher then $1 \mathrm{~Hz}$, an external pump is needed to maintain the required $P_{\text {cell }}$ and $\tau$.

The measurement cell has a volume of $0.55 \times 10^{-3} \mathrm{~m}^{3}$ and a length of $0.20 \mathrm{~m}$ (Fig. 1). Data output is provided in analogue as well as digital format (RS232\&TCP/IP) and the de- 
vice can store data up to 10 gigabytes. Warm-up time is approximately one minute and measurements as well as performance can be observed on a colour TFT LCD flat panel display. The dimensions of the FMA are $0.25 \mathrm{~m}$ height, $0.97 \mathrm{~m}$ width and $0.36 \mathrm{~m}$ depth and it has a weight of $22 \mathrm{~kg}$. Power requirements are $115 / 230 \mathrm{VAC}, 50 / 60 \mathrm{~Hz}$ and $180 \mathrm{~W}$ and inlet/outlet fittings are of the Swagelok type $(3 / 8,, 1 / 4 ")$.

\subsection{Site description}

Besides testing in the laboratory, the FMA was tested in an eddy covariance set-up at the Horstermeer measurement site. This site is located in a eutrophic peat meadow area in the central part of the Netherlands and was described extensively by Hendriks et al. (2007). The area has a flat topography and vegetation consists of grasses, small shrubs and reeds. Before, $\mathrm{CH}_{4}$ fluxes in the area were measured with the flux chamber technique and variation between three land elements was observed: emissions from the saturated land and water surfaces were high compared to the relatively dry land. The annual weighted $\mathrm{CH}_{4}$ emission at the site over 2005 and 2006 was estimated at $83.95 \pm 54.81 \mathrm{nmol} \mathrm{m}^{-2} \mathrm{~s}^{-1}$ (Hendriks at al., 2007).

\subsection{Assessment of instrument stability, precision and accu-} racy

System stability is a major factor influencing high-sensitivity measurements. Theoretically, the signal from a perfectly stable system could be averaged infinitely. However, real systems are stable only for a limited time period. The length of time over which a laser signal can be averaged to achieve optimum sensitivity, and thus high precision, largely determines the quality of the spectrometer. The precision of concentration measurements should be at least a few parts per thousand of the ambient mixing ratio., which is approximately $4 \mathrm{ppb}$ for a mixing ratio of approximately $1800 \mathrm{ppb}$ (outside air) in the case of $\mathrm{CH}_{4}$ (Kroon et al., 2007). Both maximum system stability and precision can be determined using the Allan variance (Allan, 1966; Werle et al., 1993; Nelson et al., 2004; Kroon et al., 2007). The Allan variance $\left(\sigma_{A}^{2}\right)$, as a function of integration time $\mathrm{T}$, is the average of the sample variance of two adjacent averages of time series of data and is described by Eq. (2):

$$
\left\langle\sigma_{A}^{2}(k)\right\rangle_{t}=\frac{1}{2 m} \sum_{s=1}^{m}\left[A_{s+1}(k)-A_{s}(k)\right]^{2}
$$

with: $A_{s}(k)=\frac{1}{k} \sum_{l=1}^{k} x_{(s+1) k+l}$,

with: $s=1, \ldots ., m$ and $m=m^{\prime}-1$.

In this equation $A$ is an average of the $\mathrm{CH}_{4}$ concentration, $k$ is the number of elements in subgroup $x, s$ is the subgroup number, $l$ is the sample-number in the subgroup, and $m^{\prime}$ the number of independent measurements. It is assumed that data are collected over a constant data interval $\Delta t$, therefore
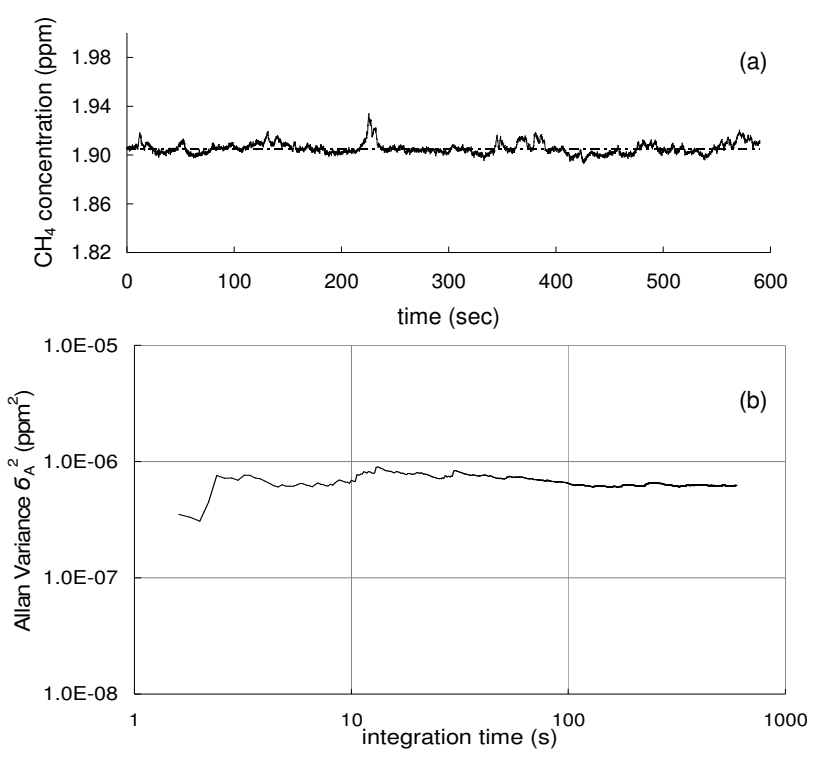

Fig. 2. Time series of $\mathrm{CH}_{4}$ concentration measurements with $10 \mathrm{~Hz}$ sampling rate with a mean of $1905 \mathrm{ppb}$ and a standard deviation of $4.74 \mathrm{ppb}$ (a) and the Allan variance plot for these data (b).

the integration time $T=k \Delta t$ (Allan, 1966; Werle et al., 1993; Nelson et al., 2004). The Allan variance decreases when random noise dominates over drift effects. However, when noise caused by instrumental drift of the system starts to dominate, the Allan variance starts to increase, indicating a decrease of system stability and hence precision. $\mathrm{CH}_{4}$ concentration measurements over a ten minute period of relative constant $\mathrm{CH}_{4}$ concentrations with a mean value of $1905 \mathrm{ppb}$ and a standard deviation of $4.74 \mathrm{ppb}$ with $10 \mathrm{~Hz}$ sampling rate were used to determine the Allan variance. Subsequently, the Allan variance of this period was plotted over the integration time $T$ (Fig. 2), showing a decreasing Allan variance over integration times larger than $2.4 \mathrm{~s}$. No increase of the Allan variance was observed at larger integration times, indicating an absence of instrumental drift, and thus high system stability and precision, for integration times of a few seconds up to ten minutes. Additionally, an indication for the short term precision $(\sigma)$ was obtained by the y-axis intercept at the minimum Allan variance $\left(\sigma_{A s}^{2}=6.1 \times 10^{-3} \mathrm{ppb}^{2}\right)$. Using Eq. (3):

$\sigma=\sigma_{A s} \times f_{s}^{-1 / 2}$

in which $\sigma_{A s}$ is the square root of the minimum Allan variance and $f_{s}$ is the sampling frequency of the system $(10 \mathrm{~Hz})$, $\sigma$ was determined as $7.8 \times 10^{-3} \mathrm{ppb} \mathrm{Hz}^{-1 / 2}$. Precisions of $0.3 \mathrm{ppb} \mathrm{Hz}^{-1 / 2}$ (Nelson et al., 2004) and $2.9 \mathrm{ppb} \mathrm{Hz}^{-1 / 2}$ (Kroon et al., 2007) were found in previous studies of QCL instruments.

Next, a calibration experiment was carried out by administering standard gas mixtures with concentrations of $125 \mathrm{ppb}$ and $2002 \mathrm{ppb} \mathrm{CH}_{4}$, both with an accuracy of $0.2 \mathrm{ppb}$, to the FMA at ten instances within a 10-day period. During the 
Table 1. Results of the 10-day calibration experiment with two standard gases of 125 and 2002 ppb respectively. Time elapsed since start of experiment, $\mathrm{CH}_{4}$ concentrations measured by FMA $\left(M_{L}\right.$ and $\left.M_{H}\right), M D$ values and $F_{\text {cal }}$ values are shown.

\begin{tabular}{|c|c|c|c|c|c|c|c|}
\hline \multicolumn{8}{|c|}{ Calibration experiment FMA } \\
\hline \multirow{2}{*}{\multicolumn{2}{|c|}{ Measurement date and time }} & \multirow{3}{*}{$\begin{array}{c}\text { Time elapsed (days) } \\
0\end{array}$} & \multicolumn{2}{|c|}{ low $\mathrm{CH}_{4}$ gas $(125 \mathrm{ppb})$} & \multicolumn{2}{|c|}{ high $\mathrm{CH}_{4}$ gas (2002 ppb) } & \multirow{3}{*}{$\begin{array}{c}F_{\text {cal }} \\
0.998\end{array}$} \\
\hline & & & $M_{L}(\mathrm{ppb})$ & $M D_{L}$ & $M_{H}(\mathrm{ppb})$ & textitMD $_{H}$ & \\
\hline 02/04/07 & 11:50:00 & & 125 & $-0.1 \%$ & 2005 & $0.2 \%$ & \\
\hline 03/04/07 & 09:00:00 & 0.882 & 127 & $1.5 \%$ & 1999 & $-0.1 \%$ & 1.003 \\
\hline 03/04/07 & 15:30:00 & 1.153 & 125 & $-0.1 \%$ & 1999 & $-0.1 \%$ & 1.002 \\
\hline 04/04/07 & 09:20:00 & 2.896 & 125 & $-0.1 \%$ & 2000 & $-0.1 \%$ & 1.001 \\
\hline 04/04/07 & $16: 45: 00$ & 2.205 & 125 & $-0.1 \%$ & 1999 & $-0.1 \%$ & 1.002 \\
\hline 05/04/07 & 09:30:00 & 2.903 & 125 & $-0.1 \%$ & 1999 & $-0.1 \%$ & 1.002 \\
\hline 05/04/07 & 17:30:00 & 3.236 & 124 & $-0.9 \%$ & 2001 & $0.0 \%$ & 1.000 \\
\hline $10 / 04 / 07$ & 09:45:00 & 7.913 & 125 & $-0.1 \%$ & 2004 & $0.1 \%$ & 0.999 \\
\hline $11 / 04 / 07$ & 09:40:00 & 8.910 & 125 & $-0.1 \%$ & 2002 & $0.0 \%$ & 1.000 \\
\hline $11 / 04 / 07$ & 16:30:00 & 9.194 & 125 & $-0.1 \%$ & 2002 & $0.0 \%$ & 1.000 \\
\hline $12 / 04 / 07$ & 09:15:00 & 9.892 & 125 & $-0.1 \%$ & 2004 & $0.1 \%$ & 0.999 \\
\hline
\end{tabular}

whole experiment the FMA was never turned off in order to imitate longer measurement periods as will be the case in the field set-up. The deviation from the standard gas values of $\mathrm{CH}_{4}$ (MD) was calculated for each measurement by Eq. (4):

$M D=\frac{M-S}{S}$

where $M$ is the measured $\mathrm{CH}_{4}$ concentration in ppb and $S$ is the $\mathrm{CH}_{4}$ concentration of the standard gas in ppb. A twopoint calibration factor $\left(F_{\text {cal }}\right)$ was calculated for each set of measurements by Eq. (5):

$F_{\text {cal }}=\frac{S_{H}-S_{L}}{M_{H}-M_{L}}$

where $S_{H}$ and $S_{L}$ are the high and low standard values of $\mathrm{CH}_{4}$ in ppb and $M_{H}$ and $M_{L}$ are the high and low measured values of $\mathrm{CH}_{4}$ in ppb. Although the measured concentration sometimes varied one or two ppb from the standard values over the experimental period for both gases, no actual drift was observed in the instrument (Table 1). $F_{\text {cal }}$ was 1.000 on average with fluctuations $<0.30 \%$, indicating high accuracy of the FMA.

Additionally, over a period of a week, $\mathrm{CH}_{4}$ concentration measurements at the Horstermeer site were compared with $\mathrm{CH}_{4}$ concentrations measured at 20 and $60 \mathrm{~m}$ height at a measurement site in Cabauw $\left(51^{\circ} 58^{\prime} \mathrm{N} \text { and } 4^{\circ} 55^{\prime} \mathrm{E}\right)^{1}$, approximately $30 \mathrm{~km}$ from the Horstermeer site. The $\mathrm{CH}_{4}$ concentrations at Cabauw were measured with a Carlo Erba gas chromatograph system and have a precision of $2 \mathrm{ppb}$. The $\mathrm{CH}_{4}$ concentration at the Horstermeer site was $15 \mathrm{ppb}$ higher on average, which might be the result of the relatively high $\mathrm{CH}_{4}$

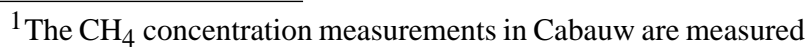
with a gas chromatograph by the Energy Centre of the Netherlands (ECN).
}

emissions from the peat meadow area in which the measurements were taken. Nonetheless, the increasing trend of $\mathrm{CH}_{4}$ concentration at the Horstermeer site was similar to the trend at the Cabauw site. Generally, slow variation in concentrations is caused by the difference between continental and marine background concentration, the continental concentration being approximately $50 \mathrm{ppb}$ higher (Eisma et al., 1994). During the measurement period, prevailing winds were from the east (continental). This accounted for the slow rise in $\mathrm{CH}_{4}$ concentrations at both measurement locations.

The influence of changing temperature and pressure conditions in the measurement cell on $\mathrm{CH}_{4}$ concentration measurements was assessed in the laboratory. During a time series of continuous measurements, a step change in $P_{\text {cell }}$ was induced, while the temperature in the measurement cell ( $\left.T_{\text {cell }}\right)$ increased steadily. An effect of the increase of $T_{\text {cell }}$ on $\mathrm{CH}_{4}$ concentration was observed neither from the time series, nor from the correlation plots (Fig. 3). A decrease in the $\mathrm{CH}_{4}$ concentration data was observed $990 \mathrm{~s}$ after the sharp decrease in $P_{\text {cel }}$. However, this feature did not result in a clear correlation between $\mathrm{CH}_{4}$ concentration and $P_{\text {cell }}$. Also, this type of $P_{\text {cell }}$ changes did not occur under normal circumstances when $P_{\text {cell }}$ had a stable value near $210 \mathrm{hPa}$.

\subsection{Incorporation of FMA in eddy covariance system}

After testing in the laboratory, the FMA was installed in a closed-path eddy covariance field set-up (Fig. 4). In order to obtain $10 \mathrm{~Hz}$ measurements, a dry vacuum scroll pump (XDS35i, BOC Edwards, Crawly, UK) was used with a maximum pumping speed of $9.72 \times 10^{-3} \mathrm{~m}^{3} \mathrm{~s}^{-1}$. However, at the required pressure of $210 \mathrm{hPa}$ the actual pumping speed was $5.50 \times 10^{-3} \mathrm{~m}^{3} \mathrm{~s}^{-1}$. The scroll pump has relatively high power requirements: $100 / 200 \mathrm{~V}$ to $120 / 230 \mathrm{~V}, 50 / 60 \mathrm{~Hz}$ and $600 \mathrm{~W}$. It was placed at the end of the set-up, connected to 

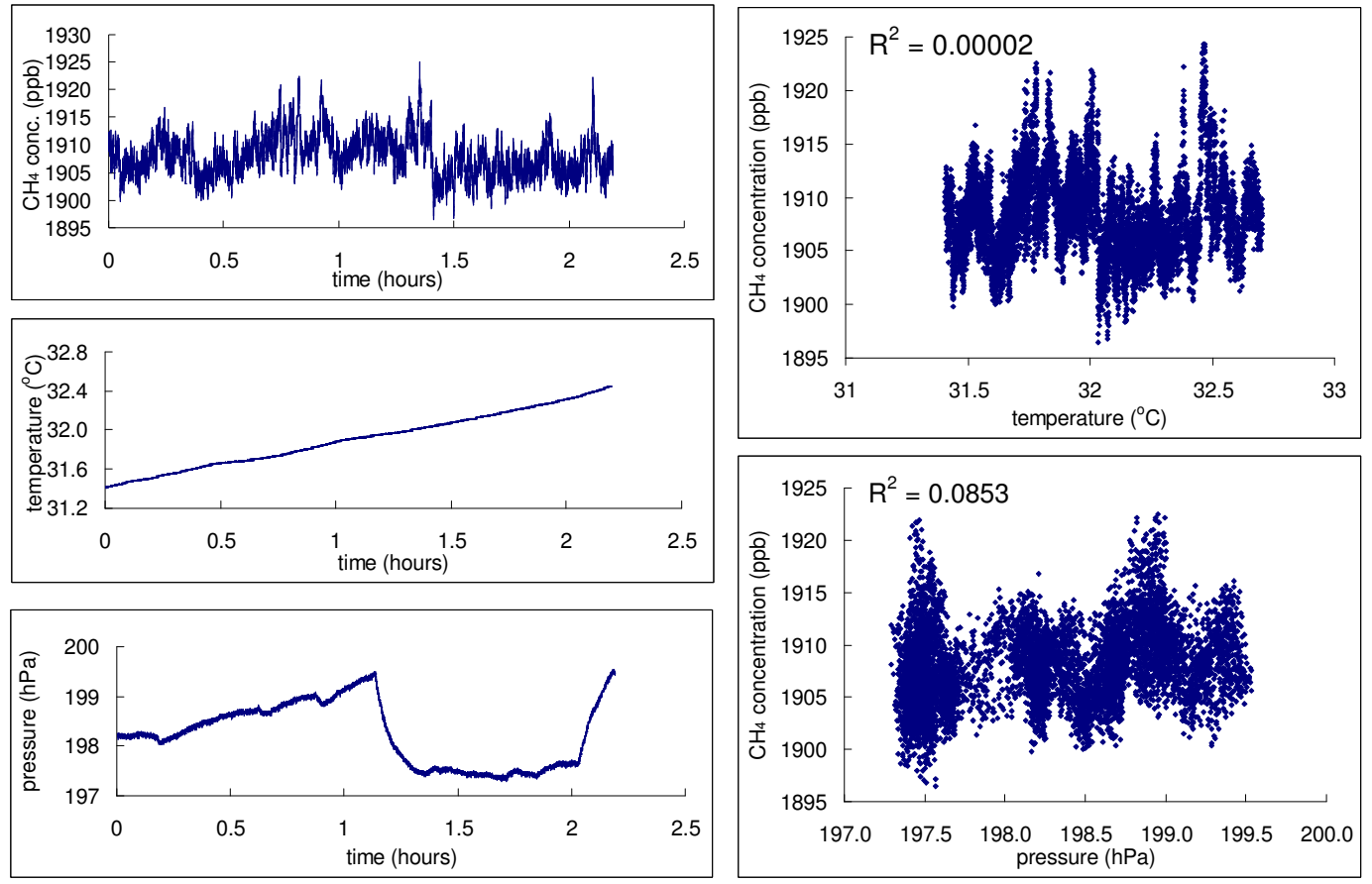

Fig. 3. Results of the laboratory experiment on the effect of $T_{\text {cell }}$ and $P_{\text {cell }}$ on $\mathrm{CH}_{4}$ concentration measurements. (a) time series of $\mathrm{CH}_{4}$ concentration measurements; (b) time series of $T_{\text {cell }}$ measurements; (c) time series of $P_{\text {cell }}$ measurements; $(\mathbf{d})$ scatter plot of $\mathrm{CH}_{4}$ concentration against $T_{\text {cell }}$ with correlation coefficient $\left(R^{2}\right)$; (e) scatter plot of $\mathrm{CH}_{4}$ concentration against $P_{\text {cell }}$ with $R^{2}$.

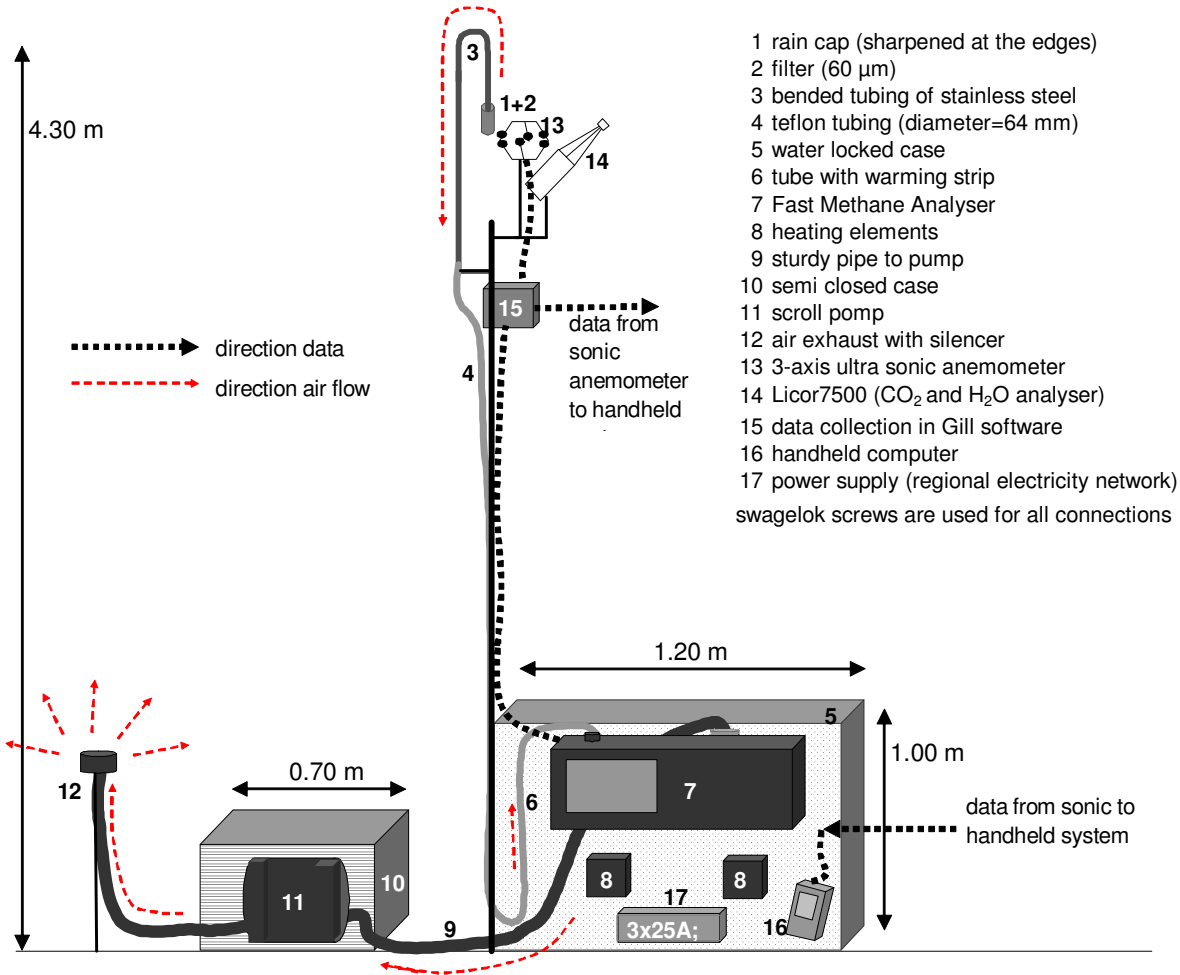

Fig. 4. Schematic overview of the combined field set-up of the closed path eddy covariance system for $\mathrm{CH}_{4}$ using the FMA and the open path eddy covariance system for $\mathrm{CO}_{2}$ and water vapour. 


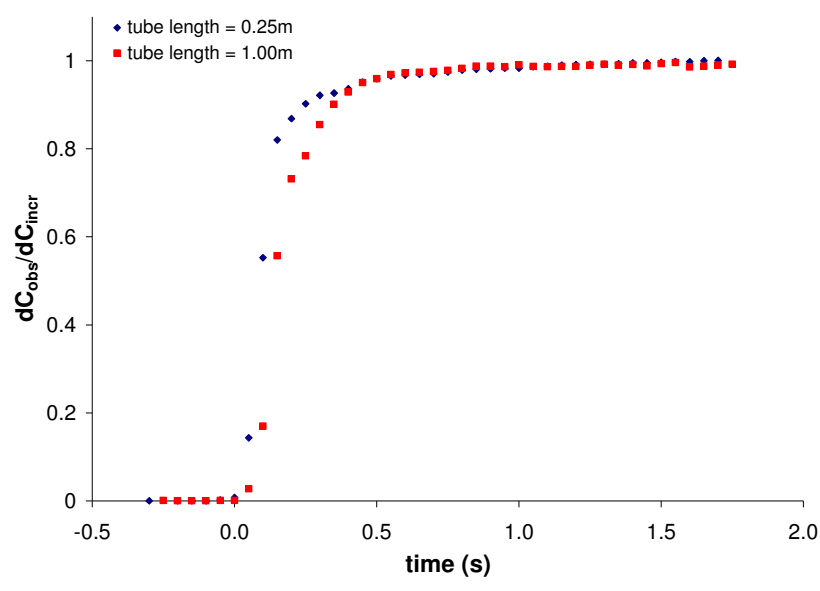

Fig. 5. Averaged and normalised time series of $\mathrm{CH}_{4}$ concentration data showing the instrument response with $20 \mathrm{~Hz}$ sampling rate changing from ambient air to a gas sample with a high $\mathrm{CH}_{4}$ concentration for tube lengths of $0.25 \mathrm{~m}$ and $1.0 \mathrm{~m}$.

the FMA by a wire-reinforced tube with an internal diameter of $1.9 \times 10^{-3} \mathrm{~m}$, sucking air through the system. The FMA was placed in a heated, water resistant box, while the scroll pump was placed in an aerated box that prevented it from getting wet and from overheating. In addition to the internal filter with a pore size of $2 \mu \mathrm{m}$ (Swagelok part no. SS-4FW42), a filter with a pore size of $60 \mu \mathrm{m}$ was placed at the inlet in order to prevent dust, aerosols, insects and droplets from entering the tubing. The inlet was shielded from the rain by a stainless steel cap. To prevent any water that accidentally passed the first filter from moving down toward the analyzer the air was first led up through a stainless steel tube (diameter of $6.4 \times 10^{-3} \mathrm{~m}$ ) that bends sharply at $0.5 \mathrm{~m}$ after which the air moves down toward the analyzer through a Teflon tube (diameter of $6.4 \times 10^{-3} \mathrm{~m}$ ). After the air has passed through the FMA measurement cell it flows through the scroll pump and was exhausted through a silencer. The gas-inlet filter was positioned $0.2 \mathrm{~m}$ away from the LI-7500 open path infrared gas analyzer (LI-COR Lincoln, NE, USA) and a Windmaster Pro 3-axis ultrasonic anemometer (GILL Instruments Limited, Hampshire, UK) directed into the prevailing wind. Both instruments were installed at $4.3 \mathrm{~m}$ above the surface at the Horstermeer measurement site (Hendriks et al., 2007). Data were logged digitally on a handheld computer at a rate of $10 \mathrm{~Hz}$ (Van der Molen et al., 2006).

\subsection{Assessment of FMA in measuring $\mathrm{CH}_{4}$ fluxes}

In general a sampling rate of $10 \mathrm{~Hz}$, with a Nyquist frequency of $5 \mathrm{~Hz}$, is used for eddy covariance techniques (Aubinet et al., 2000; Kroon et al. 2007). Therefore an instrumental time response of $10 \mathrm{~Hz}$ or greater is required in order to correlate with the wind measurements made with the 3 -axis ultrasonic anemometer. The measurement rate of an instrument is de- termined by both electronic signal processing and by the $\tau$ of the measurement cell (Nelson et al., 2004). Electronic signal processing is dependent on the spectral complexity of the measurement technique as well as the technical design of the ICOS technique. In the case of the FMA, this was defined by the designers (Los Gatos Research Ltd.) as $20 \mathrm{~Hz}$. The limiting factor of the maximum sampling rate is often $\tau$, which could be determined by the volume of the measurement cell $\left(0.55 \times 10^{-3} \mathrm{~m}^{3}\right)$ divided by the actual pumping speed $\left(5.50 \times 10^{-3} \mathrm{~m}^{3} \mathrm{~s}^{-1}\right)$ giving a flow response of $0.10 \mathrm{~s}$. Additionally, $\tau$ was determined by applying a step change in concentrations at $20 \mathrm{~Hz}$ sampling rate (Fig. 5) (Moore, 1986; Zahniser et al., 1995; Nelson et al., 2004). Each data point was the average mixing ratio of multiple step change events at a certain $t$ (time elapsed since step change in concentration). The $\tau$ was defined by the exponential fit to the decay of the $\mathrm{CH}_{4}$ mixing ratio and was calculated $\tau=0.11 \mathrm{~s}$ by Eq. (6):

$$
\left[\mathrm{CH}_{4}\right]_{t}=\left[\mathrm{CH}_{4}\right]_{t=0} e^{(-t / \tau)}
$$

where $\left[\mathrm{CH}_{4}\right]_{t}$ is the $\mathrm{CH}_{4}$ concentration at instance $t$. In this, sensitivity to tube length could be observed (Fig. 5). The data in the graph are normalized by the transformation $d C_{\mathrm{obs}} / d C_{\mathrm{incr}}$, where $d C_{\mathrm{obs}}$ is the increase of $\left[\mathrm{CH}_{4}\right]$ between the starting time and time $t$ and $d C_{\mathrm{incr}}$ is difference between the final $\left[\mathrm{CH}_{4}\right]$ and $\left[\mathrm{CH}_{4}\right]$ at the starting time. Since the effect of tube damping was corrected separately, and $\tau$ only refers to the response of the instrument itself, the actual $\tau$ was determined as $0.10 \mathrm{~s}$.

The suitability of the FMA eddy covariance set-up was further evaluated by examining the power spectra of $w$ and $\left[\mathrm{CH}_{4}\right]$ and co-spectrum of the covariance $w^{\prime}\left[\mathrm{CH}_{4}\right]^{\prime}$ (Stull et al., 1988; Kaimal and Finnigan, 1994). For this purpose twelve half hours of data from two days with moderately unstable conditions were analysed. The results of the spectral analysis were averaged and binned and the logarithmic spectral and co-spectral densities were plotted against frequency (Fig. 6). Additionally, the theoretical spectra defined by Kaimal et al. (1972) and Højstrup (1981) were plotted in the graphs (Smeets et al., 1998). The power spectrum of $w$ very closely followed the whole theoretical spectrum, while both the $\left[\mathrm{CH}_{4}\right]$ power spectrum and the $w^{\prime}\left[\mathrm{CH}_{4}\right]^{\prime}$ cospectrum showed slight deviations from the theoretical spectrum. Most important is that the inertial subranges of both the power spectra and the co-spectrum were in general agreement with the theoretical curve. The $\left[\mathrm{CH}_{4}\right]$ power spectrum showed a slight tendency to extend upward in the low frequency range. This was also observed in the $\left[\mathrm{CO}_{2}\right]$ power spectrum from the LI-7500 analyzer at the site (Hendriks et al., 2007), indicating that the upward tendency in the low range was not instrument related, but was rather an effect of environmental factors. Kaimal et al. (1976) found high densities of low frequencies in the temperature power spectrum in response to a diurnal cycle. Since a diurnal cycle was observed for both $\left[\mathrm{CO}_{2}\right]$ and $\left[\mathrm{CH}_{4}\right]$ at the Horstermeer site, 
this might have been the cause of the upward tendency observed in the power spectra. However, the overestimation of low frequencies will automatically cause an underestimation of the high frequencies, since the total area under the power spectrum is a fixed surface (Kaimal et al., 1972; Højstrup, 1981). Considering the $w^{\prime}\left[\mathrm{CH}_{4}\right]^{\prime}$ co-spectrum, the observed peak near $n=10^{-1} \mathrm{~Hz}$ generally matched the peak of the theoretical spectrum and was agreement with spectral analysis of $\mathrm{CH}_{4}$ flux measurements by Verma et al. (1992), Kormann et al. (2001) and Werle and Kormann (2001). The spectral performance of the eddy covariance set-up for temperature and $\mathrm{CO}_{2}$ fluxes were discussed previously in a paper by Hendriks et al. (2007) and were in agreement with the spectral analyses of the $\mathrm{CH}_{4}$ flux measurements.

Additionally, in previous research by Hendriks et al. (2007) the energy balance consisting of the eddy covariance measurements of latent heat and sensible heat, the micro-meteorological measurements of incoming and reflected radiation components and the ground heat flux showed a closure of $82 \%$. This indicated that the data from the eddy covariance set-up were acceptable (Lloyd et al., 1997).

The travel time of the air in the closed path set-up from the inlet filter to the FMA, caused a time lag with respect to the in situ measured wind data. For 20 half hour periods, the covariance $w^{\prime}\left[\mathrm{CH}_{4}\right]^{\prime}$ of $w^{\prime}$ at instance $t=0.0 \mathrm{~s}$ and $\left[\mathrm{CH}_{4}\right]^{\prime}$ at $t=0.0 \mathrm{~s}$ was determined, as well as the covariance of $w^{\prime}$ at $t=0.0 \mathrm{~s}$ and $\left[\mathrm{CH}_{4}\right]^{\prime}$ at the $t=0.1 \mathrm{~s}, t=0.2 \mathrm{~s}, t=0.3 \mathrm{~s}, \ldots, t=2.0 \mathrm{~s}$. For all half hour periods the highest value of $w^{\prime}\left[\mathrm{CH}_{4}\right]^{\prime}$ occurred with $\left[\mathrm{CH}_{4}\right]^{\prime}$ at $t=0.6 \mathrm{~s}$. For the calculation of the actual covariance the time lag of the $\mathrm{CH}_{4}$ measurements compared to the wind measurements was therefore taken as $0.6 \mathrm{~s}$.

\subsection{Data processing}

The EUROFLUX methodology (Aubinet et al., 2000) was applied to the eddy covariance data to calculate the $\mathrm{CH}_{4}$ fluxes from the closed path system and the $\mathrm{CO}_{2}$ fluxes from the open path system (Hendriks et al., 2007) on a thirty minute basis. Since system instrumental drift was not observed, an overestimation of the fluxes as a result of this averaging period was not expected. The damping effect of the $\tau$ on the $\mathrm{CH}_{4}$ signal was corrected for in the flux calculation procedure as well as for the time lag of $0.6 \mathrm{~s}$ between closed path $\mathrm{CH}_{4}$ and open path wind, temperature and $\mathrm{CO}_{2}$ measurements (Moore et al., 1986). The tube length of the set-up was over 1000 times the inner diameter of the tube and therefore the air temperature in the measurement cell could be considered stable. As a result, the Webb correction for density fluctuations arising from variations in temperature that was applied to the open path $\mathrm{CO}_{2}$ measurements, was not required for the closed path measurements of $\mathrm{CH}_{4}$ (Leuning and Moncrieff, 1990). The Webb correction for density fluctuations arising from variations in water vapour (measured with the LI-7500) was applied according
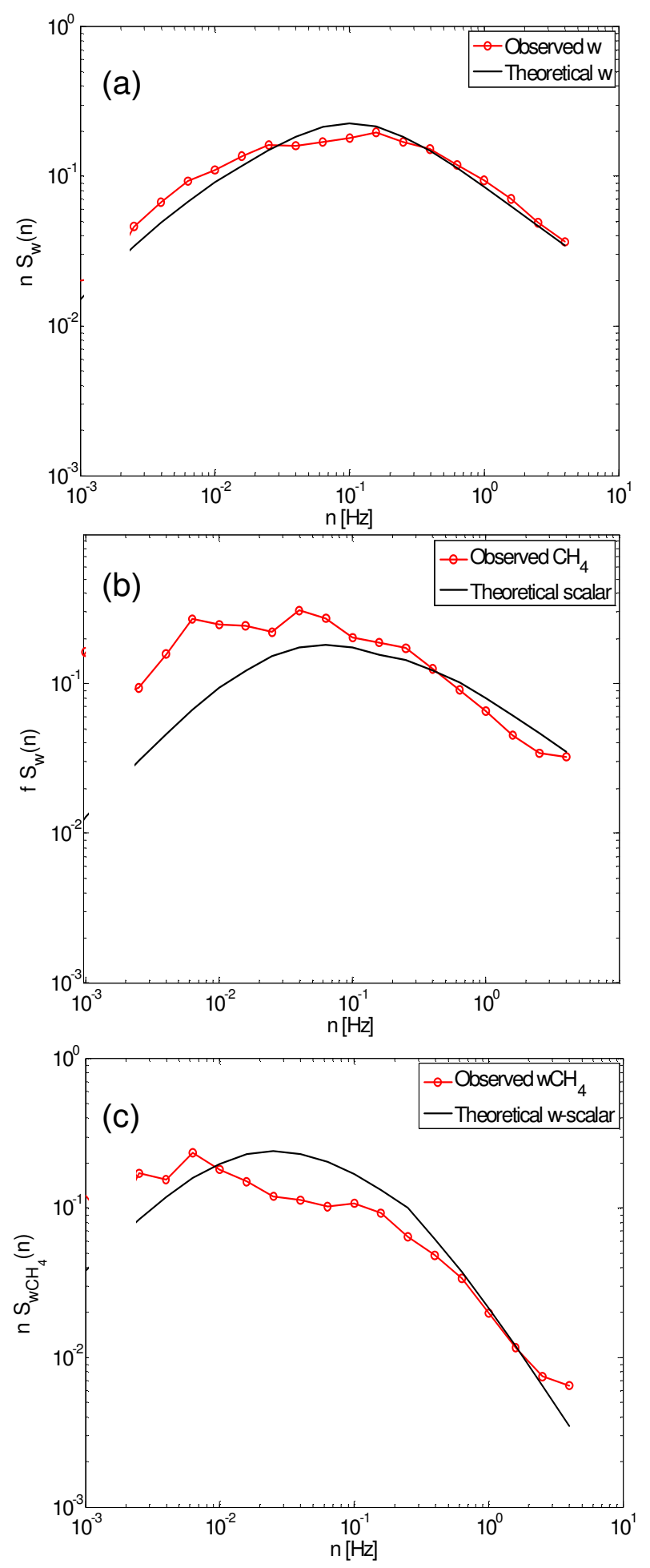

Fig. 6. Averaged and binned results of the spectral analyses of the FMA eddy covariance set-up for two moderately turbulent days (six half hour periods per day). (a) Observed and theoretical power-spectrum $w$; (b) Observed and theoretical power-spectrum of $\left[\mathrm{CH}_{4}\right]$; (c) Observed and theoretical co-spectrum of $w^{\prime}\left[\mathrm{CH}_{4}\right]^{\prime}$. 
to Leuning and Moncrieff (1990). Frequency loss corrections for closed-path systems were applied according to the theory of Leuning and King (1992). Since 3-axis ultrasonic anemometers were found to under measure wind speed at large angles, the method of Nakai et al. (2006) was used to apply the angle of attack dependent calibration (Gash and Dolman, 2003; Van der Molen et al., 2004).

\subsection{Simulation of alternative flux measurement approaches}

In eddy covariance, the sampling rate determines the number of samples that are taken out of an infinitely large number of samples. The higher the sampling rate, the higher the statistical reliability, which results in higher accuracy of the observed means and covariances (Van der Molen, 2002). In order to obtain reliable estimates of fluxes, a sampling rate of at least $10 \mathrm{~Hz}$ is generally used for eddy covariance techniques. However, measurements performed at lower rates than $10 \mathrm{~Hz}$ can generate reliable results too (Rinne et al., 2000 and 2001; Graus et al., 2006; Businger and Oncley, 1990). $1 \mathrm{~Hz}$ eddy covariance, disjunct eddy covariance, $1 \mathrm{~Hz}$ eddy covariance and relaxed eddy accumulation (REA) are possible alternatives for the preferred $10 \mathrm{~Hz}$ eddy covariance. These measurement techniques could make the external pump of the FMA eddy covariance set-up superfluous and thus save over half of the energy required for the eddy covariance set-up. This might be necessary for operation in remote places where an external power source is not available. Here, the raw $\mathrm{CH}_{4}$, $\mathrm{CO}_{2}$ and water vapour $10 \mathrm{~Hz}$ field data were manipulated to simulate $1 \mathrm{~Hz}$ eddy covariance, disjunct eddy covariance and REA.

With $1 \mathrm{~Hz}$ eddy covariance, $F_{s}$ is determined in the same manner as $10 \mathrm{~Hz}$ eddy covariance (Eq. 2), but at a lower frequency. The method was tested by averaging each 10 consecutive data points of $\mathrm{CH}_{4}$ concentration as well as wind velocity for the $10 \mathrm{~Hz}$ data set, thereby simulating a slower sampling rate $(1 \mathrm{~Hz})$ with a longer $\tau(1.0 \mathrm{~s}$ instead of $0.10 \mathrm{~s})$.

Disjunct eddy covariance uses a subset of the whole $10 \mathrm{~Hz}$ time series to determine the flux of an atmospheric property $F_{S}$ according to Eq. (7):

$F_{s}=<w^{\prime} s^{\prime}>=\frac{1}{N} \times \sum_{i=1}^{N} w_{i}^{\prime} s_{i}^{\prime}$

where $N$ is the subset of the data (Rinne et al., 2000 and 2001). Here, the disjunct eddy covariance method was tested by sampling the first data point of every 10 data points from the $10 \mathrm{~Hz}$ data set, thereby creating a time interval of $0.9 \mathrm{~s}$ between the sampling moments, while the $\tau$ remained $0.10 \mathrm{~s}$. To build a field set-up for disjunct $1 \mathrm{~Hz}$ eddy covariance a "snap sampling" instrument would have to be mounted in front of the inlet of the system to obtain samples that are sampled with a frequency of $1 \mathrm{~Hz}$, while maintaining the sampling duration as short as possible ("snap"). This method would give the FMA an analysis time of $1.0 \mathrm{~s}$ instead of $0.10 \mathrm{~s}$.

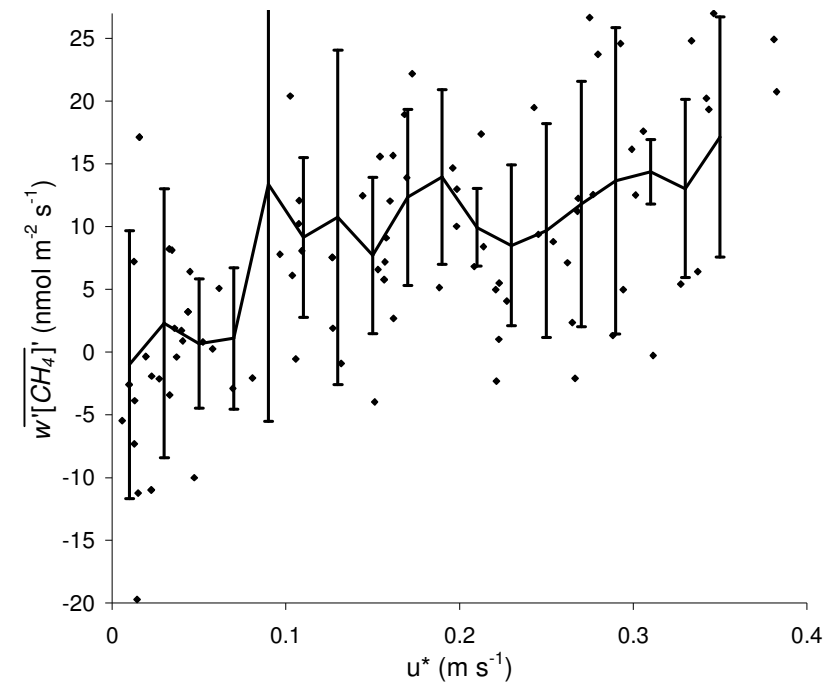

Fig. 7. Results of the analyses of the effect of low turbulence on nightly $\mathrm{CH}_{4}$ fluxes, showing a drop in flux magnitude below of $u_{*}$ of $0.09 \mathrm{~m} \mathrm{~s}^{-1}$. Data are binned over $u_{*}$ classes of $0.02 \mathrm{~m} \mathrm{~s}^{-1}$ and error bars show the standard deviation per class.

REA is a conditional sampling method in which air samples are drawn into two separate reservoirs depending on the direction of $w$. The criterion of valve switching is based on values of the standard deviation of $w\left(\sigma_{w}\right)$, which is measured by the 3 -axis ultrasonic anemometer at $10 \mathrm{~Hz}$. The valve is activated according to the threshold condition $\left|w_{0}\right|=0.6 \sigma_{w}$. In the case of $-\left|w_{0} \leq\right| w \leq \mid w_{0}$ (deadband values), neither "up" nor "down" samples are taken, but samples are discarded from the sampling system (Graus et al., 2006). Here, we simulated REA by dividing all eddy covariance data points of one half hour measurement period into three data matrices based on the direction of the $w$ (upward, downward and deadband values). Next, the measured concentrations are summed and the turbulent flux of the scalar $s$ $\left(F_{s}\right)$ was determined according to Eq. (8):

$F_{s} \approx b \times \sigma_{w} \times \Delta s$

(Businger and Oncley, 1990). The $b$-value is the correction for the deadband and $\Delta s$ the difference between the concentrations in the accumulation reservoirs (Bowling et al., 1999).

\section{Results}

\subsection{First data series}

From the eddy covariance data series $11 \%$ consisted of gaps due to failure of the eddy covariance set-up caused by rain events and instrumental errors. Additionally, $3 \%$ of the data series consisted of spikes $\left(\mathrm{CH}_{4}\right.$ flux $>100.0 \mathrm{nmol} \mathrm{m}^{-2} \mathrm{~s}^{-1}$ and $\mathrm{CH}_{4}$ flux $\left.<-10.0 \mathrm{nmol} \mathrm{m}^{-2} \mathrm{~s}^{-1}\right)$ and were removed from the data set. During night time periods with low friction 

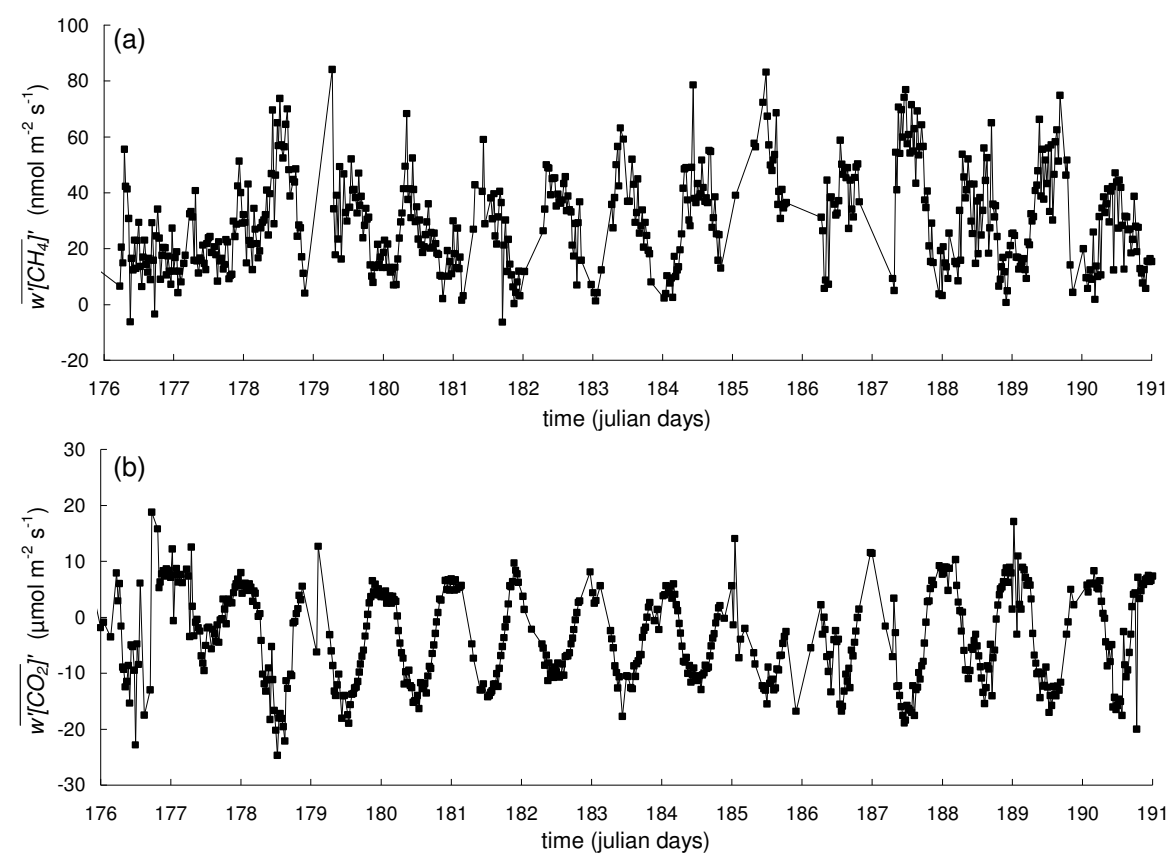

Fig. 8. $\mathrm{CH}_{4}$ flux data series over a two week period in the summer of 2006 (a) and $\mathrm{CO}_{2}$ flux (NEE) data series over the same period (b).

velocity $\left(u_{*}\right)$ the turbulence of the atmosphere can become too low for the performance of eddy covariance measurements (Wohlfahrt et al., 2005; Dolman et al., 2004). In order to determine the critical $u_{*}$ value for $\mathrm{CH}_{4}$ eddy covariance measurements at this specific site, the $\mathrm{CH}_{4}$ flux data and $u_{*}$ data from periods with incoming shortwave radiation (SWin) $<20 \mathrm{~W} \mathrm{~m}^{-2}$ were selected (Dolman et al., 2004). The nightly $\mathrm{CH}_{4}$ fluxes showed a significant decrease for periods with $u_{*}<0.09 \mathrm{~m} \mathrm{~s}^{-1}$ (Fig. 7). This result is similar to the critical $u_{*}$ value of $0.10 \mathrm{~m} \mathrm{~s}^{-1}$ found for $\mathrm{CO}_{2}$ fluxes at the same site (Hendriks et al., 2007). $\mathrm{CH}_{4}$ flux data measured during periods with $u_{*}<0.09 \mathrm{~m} \mathrm{~s}^{-1}$ occurred at $12 \%$ of the data series and where removed too. The total amount of data gaps accounted for $26 \%$ of the whole data series.

$\mathrm{CH}_{4}$ fluxes and $\mathrm{CO}_{2}$ fluxes (net ecosystem exchange (NEE)) were plotted for a two week period in June 2006 at the Horstermeer site (Fig. 8). Although the $\mathrm{CH}_{4}$ fluxes are rather variable over time, a diurnal cycle can be observed with low emission during the night and high emission during the day. $\mathrm{CO}_{2}$ fluxes have a similar, but opposite, diurnal cycle. The observed $\mathrm{CH}_{4}$ fluxes consisted mainly of emission and had an average of $29.7 \mathrm{nmol} \mathrm{m}^{-2} \mathrm{~s}^{-1}$, while the typical maximum $\mathrm{CH}_{4}$ emission was approximately $80.0 \mathrm{nmol} \mathrm{m}^{-2} \mathrm{~s}^{-1}$. The typical minimum flux was approximately $0.0 \mathrm{nmol} \mathrm{m}^{-2} \mathrm{~s}^{-1}$ and at three occasions a small uptake was observed.

\subsection{Intercomparison with flux chamber data}

For two days during the $\mathrm{CH}_{4}$ eddy covariance measurement period at the Horstermeer site, flux chamber measurements were made in the footprint of the eddy covariance tower with a Photoacoustic Field Gas-Monitor (type 1312, Innova AirTech Instruments, Ballerup, Denmark) connected with tubes to closed, dark chambers (Hendriks et al., 2007). Flux chamber data were collected at the three land elements occurring in the footprint of the eddy covariance tower: relatively dry peat land, saturated peat land and ditch water surfaces. The fluxes from the various land elements are averaged with respect to their relative surface area $(70 \%$, $20 \%$ and $10 \%$ respectively; Hendriks et al., 2007). On June 10 the flux chamber measurements showed an average $\mathrm{CH}_{4}$ flux of $114.5 \pm 9.6 \mathrm{nmol} \mathrm{m}^{-2} \mathrm{~s}^{-1}$, while the eddy covariance measurements showed an average $\mathrm{CH}_{4}$ flux of $83.2 \mathrm{nmol} \mathrm{m}^{-2} \mathrm{~s}^{-1}$ over the same period (Fig. 9). On 3 October the average $\mathrm{CH}_{4}$ flux from the chamber measurements was $53.6 \pm 11.2 \mathrm{nmol} \mathrm{m}^{-2} \mathrm{~s}^{-1}$, while that from eddy covariance was $61.6 \mathrm{nmol} \mathrm{m}^{-2} \mathrm{~s}^{-1}$.

\subsection{Simulation of alternative flux measurement approaches}

The simulated $1 \mathrm{~Hz}$ and disjunct eddy covariance data as well as the simulated REA data were compared with the original $10 \mathrm{~Hz}$ eddy covariance data as half hourly averages over a 15 day period (Table 2). It can be observed that the various methods show similar but not identical results and that all alternative methods showed variations from the $10 \mathrm{~Hz}$ eddy 
Table 2. Summary of results of $1 \mathrm{~Hz}$ eddy covariance, disjunct eddy covariance and $\mathrm{REA}$ compared to $10 \mathrm{~Hz}$ eddy covariance for $\mathrm{CH}_{4}$, $\mathrm{CO}_{2}$ and water vapour $\left(\mathrm{H}_{2} \mathrm{O}\right)$ flux measurements. Average gas flux over the 15 day period, average deviation from the $10 \mathrm{~Hz}$ eddy covariance data and standard deviations of half hourly data are shown.

\begin{tabular}{|c|c|c|c|c|c|}
\hline & & $10 \mathrm{~Hz} \mathrm{EC}$ & $1 \mathrm{~Hz} \mathrm{EC}$ & Disjunct $1 \mathrm{~Hz}$ EC & $\operatorname{REA}(\mathrm{d}=0.6 ; \mathrm{b}=0.2)$ \\
\hline \multirow[t]{3}{*}{ average gas flux } & $\mathrm{CH}_{4}$ flux $\left(\mathrm{nmol} \mathrm{m}^{-2} \mathrm{~s}^{-2}\right)$ & 26.74 & 27.35 & 26.29 & 25.76 \\
\hline & $\mathrm{CO}_{2}$ flux $\left(\mu \mathrm{mol} \mathrm{m}^{-2} \mathrm{~s}^{-2}\right)$ & -6.53 & -5.84 & -6.31 & -6.41 \\
\hline & $\mathrm{H}_{2} \mathrm{O}$ flux $\left(\mathrm{mmol} \mathrm{m}{ }^{-2} \mathrm{~s}^{-2}\right)$ & 3.13 & 2.79 & 3.05 & 3.01 \\
\hline average deviation from normal & $\mathrm{CH}_{4}$ flux $(\%)$ & $0 \%$ & $2 \%$ & $-2 \%$ & $-4 \%$ \\
\hline \multirow[t]{2}{*}{$10 \mathrm{~Hz}$ eddy covariance } & $\mathrm{CO}_{2}$ flux $(\%)$ & $0 \%$ & $-11 \%$ & $-3 \%$ & $-2 \%$ \\
\hline & $\mathrm{H}_{2} \mathrm{O}$ flux $(\%)$ & $0 \%$ & $-11 \%$ & $-3 \%$ & $-4 \%$ \\
\hline \multirow[t]{3}{*}{ standard deviation } & $\mathrm{CH}_{4}$ flux $\left(\mathrm{nmol} \mathrm{m}{ }^{-2} \mathrm{~s}^{-2}\right)$ & 11.65 & 12.23 & 12.70 & 14.34 \\
\hline & $\mathrm{CO}_{2}$ flux $\left(\mu \mathrm{mol} \mathrm{m}^{-2} \mathrm{~s}^{-2}\right)$ & 9.95 & 9.13 & 9.86 & 11.22 \\
\hline & $\mathrm{H}_{2} \mathrm{O}$ flux $\left(\mathrm{mmol} \mathrm{m}^{-2} \mathrm{~s}^{-2}\right)$ & 2.82 & 2.59 & 2.80 & 2.77 \\
\hline
\end{tabular}
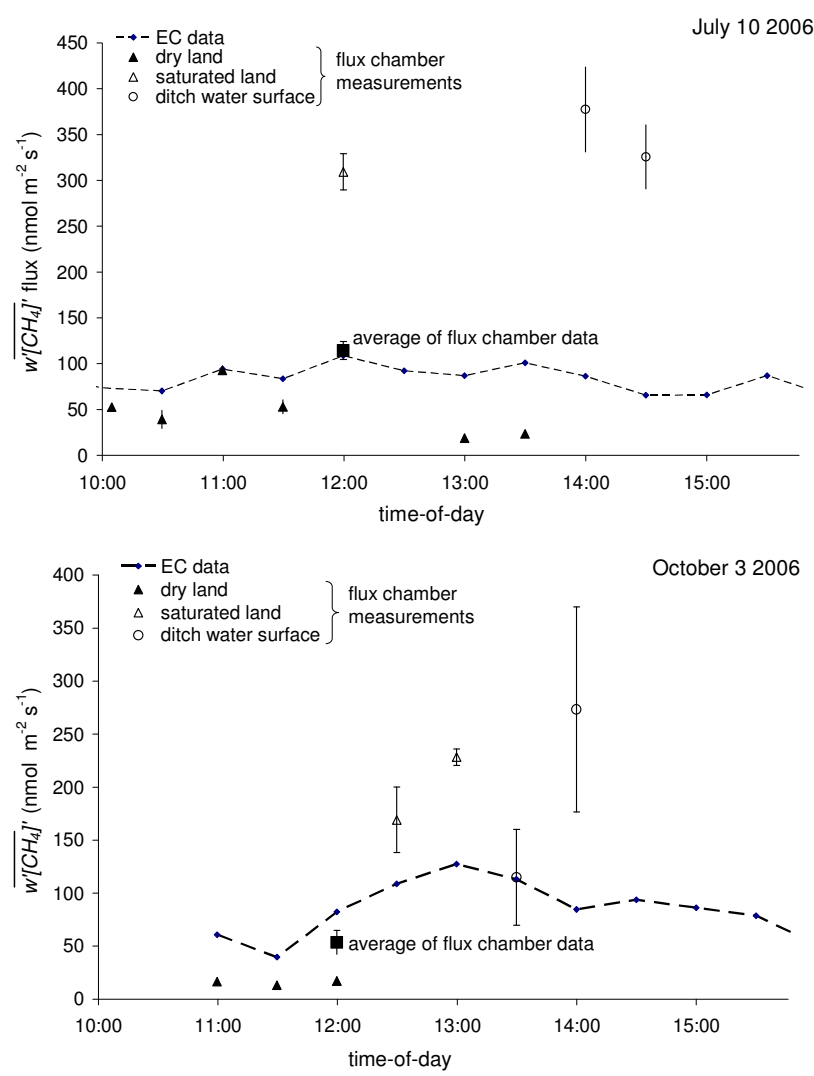

Fig. 9. Hourly $\mathrm{CH}_{4}$ flux data at 10 July and 3 October (both 2006) plotted in combination with flux chamber data from various land elements in the footprint of the eddy covariance tower collected at the same day. The square marks show the weighed average of the flux chamber measurements.

covariance data (Fig. 10). The $1 \mathrm{~Hz}$ eddy covariance method showed on average a slight overestimation of the half hourly fluxes for $\mathrm{CH}_{4}$ measurements $(2 \%)$ and the standard devi-

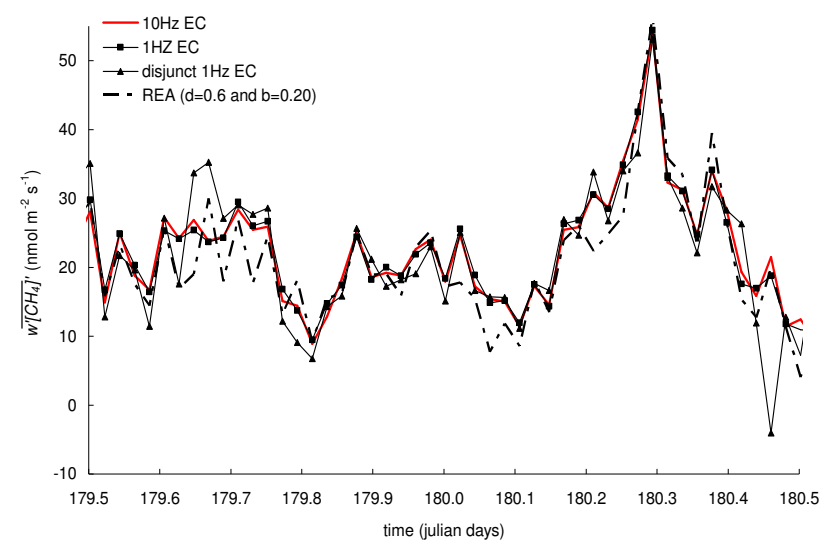

Fig. 10. Time series of $\mathrm{CH}_{4}$ fluxes for a one day period: half hourly averages of $10 \mathrm{~Hz}$ eddy covariance and simulated $1 \mathrm{~Hz}$ eddy covariance, disjunct eddy covariance, and REA.

ation of the time series was somewhat higher than that of the $10 \mathrm{~Hz}$ eddy covariance. Average $\mathrm{CO}_{2}$ and water vapour fluxes determined with $1 \mathrm{~Hz}$ eddy covariance showed however a large underestimation compared to the $10 \mathrm{~Hz}$ eddy covariance measurements. The disjunct eddy covariance method showed on average a slight underestimation of the half hourly fluxes for $\mathrm{CH}_{4}$ as well as for $\mathrm{CO}_{2}$ and water vapour measurements $(-2 \%$ and $-3 \%)$, while the standard deviation was somewhat higher than that of the $10 \mathrm{~Hz}$ eddy covariance.

The $b$-value used in REA for correction of the deadband area was determined by Pattey et al. (1993) as 0.56. For the measurement set-up investigated here, a $b$-value of 0.20 showed results most similar to the normal $10 \mathrm{~Hz}$ eddy covariance measurements for $\mathrm{CH}_{4}$ measurements as well as for $\mathrm{CO}_{2}$ and water vapour measurements. The results of the REA method showed on average a small underestimation of 
the half hourly fluxes for $\mathrm{CH}_{4}$ as well as for $\mathrm{CO}_{2}$ and water vapour measurements $(-4 \%$ and $-2 \%)$. The standard deviation however, was significantly higher than that of the $10 \mathrm{~Hz}$ eddy covariance, pointing at relatively large deviations from the $10 \mathrm{~Hz}$ measurements at a half hourly basis.

\section{Conclusions and discussion}

The FMA, which uses the new off-axis ICOS technique, was found to perform satisfactorily in laboratory experiments and in the eddy covariance field set-up. Compared to other techniques, the absence of a large nitrogen Dewar for cooling that would need weekly refill, the compact, narrow band and stable laser, the relative user friendliness and low costs are considerable advantages. The FMA eddy covariance set-up was found to perform independently in an unattended field situation. However, care should be taken when placing the instrument with a scroll pump in the field. The FMA should be kept dry and in ambient temperatures between $5^{\circ} \mathrm{C}$ and $45^{\circ} \mathrm{C}$, while the scroll pump should be kept dry and cool. Contamination of the measurement cell should be prevented, since the mirrors inside the measurement cell are sensitive and only a small contamination might cause a rapid decrease in reflectivity of the mirrors and performance of the instrument.

The analysis of the Allan variance indicated a high precision and system stability of the FMA. Additionally, the calibration experiment showed sufficiently high accuracy $(<0.30 \%)$. As long as ambient temperatures do not exceed the range of 5 to $45^{\circ} \mathrm{C}$ and pressure in the measurement cell is near $210 \mathrm{hPa}$, the $\mathrm{CH}_{4}$ measurements are not affected by changes in $T_{\text {cell }}$ and $P_{\text {cell }}$. Since no instrumental drift was observed in the Allan variance analyses, in the calibration experiment or in the comparison with $\mathrm{CH}_{4}$ concentration data at a field site nearby, it was concluded that frequent calibration of the FMA was not necessary.

The observed $\tau$ was $0.10 \mathrm{~s}$, implying a maximum sampling rate of $10 \mathrm{~Hz}$ which is sufficient for eddy covariance measurements. The closed path FMA eddy covariance system performed well, as shown by the power- and co-spectra which corresponded well to the theoretical spectral curves. Additionally, the energy balance showed satisfactory closure. $\mathrm{CH}_{4}$ fluxes appeared to be underestimated during periods with low turbulence and a $u_{*}$ correction was applied for $\mathrm{CH}_{4}$ flux data during periods with $u_{*}<0.09 \mathrm{~m} \mathrm{~s}^{-1}$. Due to erroneous measurements, spikes and periods of low turbulence the data series consisted for $26 \%$ of gaps.

Observed $\mathrm{CH}_{4}$ fluxes consisted mainly of emission, showed a diurnal cycle, but were rather variable over time. The average $\mathrm{CH}_{4}$ emission was $29.7 \mathrm{nmol} \mathrm{m}^{-2} \mathrm{~s}^{-1}$, while the typical maximum $\mathrm{CH}_{4}$ emission was approximately $80.0 \mathrm{nmol} \mathrm{m}^{-2} \mathrm{~s}^{-1}$ and the typical minimum flux was approximately $0.0 \mathrm{nmol} \mathrm{m}^{-2} \mathrm{~s}^{-1}$. These $\mathrm{CH}_{4}$ fluxes were in agreement with QCL flux measurements at a managed peat meadow site in the Netherlands (Reeuwijk), where emissions were $40 \pm 31 \mathrm{nmol} \mathrm{m}^{-2} \mathrm{~s}^{-1}$ on average (Kroon et al., 2007) and average annual $\mathrm{CH}_{4}$ emission of $30 \mathrm{nmol} \mathrm{m}^{-2} \mathrm{~s}^{-1}$ from peat lands in Germany and the Netherlands (Drösler et al., 2007). From the comparison of the eddy covariance measurements with flux chamber measurements, it was observed that the fluxes from the two techniques showed a discrepancy of approximately $20 \%$. However, considering the fact that the flux chamber measurements are point measurements at the soil surface while the eddy covariance has a footprint of hundreds of square meters, some degree of variation may be expected.

Additionally, raw $\mathrm{CH}_{4}, \mathrm{CO}_{2}$ and water vapour $10 \mathrm{~Hz}$ field data were manipulated to simulate $1 \mathrm{~Hz}$ eddy covariance, disjunct eddy covariance and REA. It was concluded that, when using a scroll pump is not possible for technical or practical reasons; disjunct eddy covariance was the most reliable substitute for $10 \mathrm{~Hz}$ eddy covariance. This method showed the highest degree of resemblance with the $10 \mathrm{~Hz}$ eddy covariance for all three gases. The simulated $1 \mathrm{~Hz}$ eddy covariance of $\mathrm{CO}_{2}$ and water vapour fluxes, showed relatively large deviations from the $10 \mathrm{~Hz}$ eddy covariance data, indicating a reduced reliability of the method and no possibility to test the validity of the method at sites without the eddy covariance set-up for $\mathrm{CH}_{4}$. Simulation of REA did show similar results for all three gases; however, the standard deviation of the time series was significantly higher than that of the $10 \mathrm{~Hz}$ eddy covariance, pointing at relatively large deviations from the $10 \mathrm{~Hz}$ measurements at the half hourly basis. REA was therefore evaluated to generate reliable estimates of fluxes over periods in the order of days or weeks. Importantly, the $b$-value for $\mathrm{CH}_{4}$ flux measurements was the same as that for the $\mathrm{CO}_{2}$ and water vapour flux measurements. This indicates that it will be possible to determine the $b$-value for $\mathrm{CH}_{4}$ measurements with REA at new and remote locations using an eddy covariance set-up with low power requirements for $\mathrm{CO}_{2}$ or water vapour. Finally, it should be taken into account that the "snap sampling" instrument for disjunct eddy covariance and the valve switching system for REA will introduce additional artefacts, which also require certain amounts of power (Rinne et al., 2000; Kuhn et al., 2005; Graus et al., 2006).

Acknowledgements. This research project is performed in the framework of the European research programme Carbo Europe (contract number GOCE-CT2003-505572) and the Dutch National Research Programme Climate Changes Spatial Planning (www.klimaatvooruimte.nl). We very much appreciate the help from A. Vermeulen working at ECN for the information and data from the Cabauw site. Also, we would very much like to thank our technical co-operators R. Stoevelaar and R. Lootens.

Edited by: W. E. Asher 


\section{References}

Allan, D. W.: Statistics of Atomic Frequency Standards, Proceedings of the Institute of Electrical and Electronics Engineers, 54(2), 221-230, 1966.

Aubinet, M., Grelle A., Ibrom, A., et al.: Estimates of the annual net carbon and water exchange of forests: The EUROFLUX methodology, Adv. Ecol. Res., 30, 113-175, 2000.

Bear, D. S., Paul, J. B., Gupta, M., et al.: Sensitive absorption measurements in the near-infrared region using off-axis integratedcavity-output spectroscopy, Appl. Phys. B, 75, 261-265, 2002.

Bowling, D. R., Delany, A. C., Turnipseed, A. A., et al.: Modification of the relaxed eddy accumulation technique to maximize measured scalar mixing ratio differences in updrafts and downdrafts, J. Geophys. Res.-Atmos., 104(D8), 9121-9133, 1999.

Businger, J. A. and Oncley, S. P.: Flux Measurement with Conditional Sampling, Journal of Atmospheric and Oceanic Technology, 7(2), 349-352, 1990.

Dolman, A. J., Maximov, T. C., Moors, E. J., et al.: Net ecosystem exchange of carbon dioxide and water of far eastern Siberian Larch (Larix cajanderii) on permafrost, Biogeosciences, 1, 133146, 2004, http://www.biogeosciences.net/1/133/2004/.

Drösler, M., Freibauer, A., Christensen, T. R., et al.: Observation and status of peatland greenhouse gas emission in Europe, in: The Continental-Scale Greenhouse Gas Balance of Europe, edited by: Dolman, H., Valentini, R., Freibauer, A., Series: Ecological Studies, Vol. 203, 305 pp., ISBN 978-0-387-76568-6, 237-255, 2008.

Eisma, R., Vermeulen, A. T., and Kieskamp, W. M.: Determination of European methane emissions, using concentration and isotope measurements, Environ. Monit. Assess., 31, 197-202, 1994.

Faist, J., Capasso, F., Sivco, D. L., et al.: Quantum Cascade Laser - Temperature-Dependence of the Performance-Characteristics and High T0 Operation, Appl. Phys. Lett., 65(23), 2901-2903, 1994.

Foster, P., Ramaswamy, V., Artaxo, P., et al.: Changes in Atmospheric Constituents and in Radiative Forcing, in: Climate Change 2007: The Physical Science Basis, Contribution of working group I to the Fourth Assessment Report of the Intergovernmental Panel on Climate Change, edited by: Solomon, S., Qin., D., Manning, M., et al., Cambridge University Press, Cambridge, United Kingdom and New York, NY, USA, 2007.

Gash, J. H. C. and Dolman, A. J.: Sonic anemometer (co)sine response and flux measurement I. The potential for (co)sine error to affect sonic anemometer-based flux measurements, Agr. Forest Meteorol., 119(3-4), 195-207, 2003.

Graus, M., Hansel, A., Wisthaler, A., et al.: A relaxed-eddyaccumulation method for the measurement of isoprenoid canopyfluxes using an online gas-chromatographic technique and PTRMS simultaneously, Atmos. Environ., 40, S43-S54, 2006.

Hargreaves, K. J., Fowler, D., Pitcairn, C. E. R., et al.: Annual methane emission from Finnish mires estimated from eddy covariance campaign measurements, Theor. Appl. Climatol., 70(14), 203-213, 2001.

Hendriks, D. M. D., van Huissteden, J., Dolman, A. J., and van der Molen, M. K.: The full greenhouse gas balance of an abandoned peat meadow, Biogeosciences, 4, 411-424, 2007, http://www.biogeosciences.net/4/411/2007/.

Højstrup, J.: A simple model for the adjustment of velocity spectra in unstable conditions downstream of an abrupt change in roughness and heat flux, Bound.-Lay. Meteorol., 21, 341-356, 1981.

Kaimal, J. C. and Finnigan, J. J.: Atmospheric boundary layer flows, their structure and management, New York, Oxford University Press, 1994.

Kaimal, J. C., Wyngaard, J. C., Haugen, D. A., et al.: Turbulence structure in convective boundary-layer, J. Atmos., 33(11), 2152 2169, 1976.

Kaimal, J. C., Izumi, Y, Wyngaard, J. C., et al.: Spectral characteristics of surface-layer turbulence, Q. J. Roy. Meteor. Soc., 98(417), 563-589, 1972.

Kormann, R., Muller, H., and Werle, P.: Eddy flux measurements of methane over the fen "Murnauer Moos", 11 degrees $11^{\prime} \mathrm{E}$, 47 degrees $39^{\prime} \mathrm{N}$, using a fast tunable diode laser spectrometer, Atmos. Environ., 35(14), 2533-2544, 2001.

Kroon, P. S., Hensen, A., Zahniser, M. S., et al.: Suitability of quantum cascade laser spectrometry for $\mathrm{CH}_{4}$ and $\mathrm{N}_{2} \mathrm{O}$ eddy covariance measurements, Biogeosciences, 4, 715-728, 2007, http://www.biogeosciences.net/4/715/2007/.

Kuhn, U., Dindorf, T., Ammann, C., et al.: Design and field application of an automated cartridge sampler for VOC concentration and flux measurements, J. Environ. Monitor., 7(6), 568-576, 2005.

Leuning, R. and Moncrieff, J.: Eddy-Covariance $\mathrm{CO}_{2}$ Flux Measurements Using Open-Path and Closed-Path $\mathrm{CO}_{2}$ Analyzers Corrections for Analyzer Water-Vapour Sensitivity and Damping of Fluctuations in Air Sampling Tubes, Bound.-Lay. Meteorol., 53(1-2), 63-76, 1990.

Leuning, R. and King, K. M.: Comparison of eddy-covariance measurements of $\mathrm{CO}_{2}$ fluxes by open-path and closed path $\mathrm{CO}_{2}$ analyzers, Bound.-Lay. Meteorol., 59(3), 297-311, 1992.

Lloyd, C. R., Bessemoulin, P., Cropley, F. D., et al.: A comparison of surface fluxes at the HAPEX-Sahel fallow bush sites, J. Hydrol., 189(1-4), 400-425, 1997.

Moore, C. J.: Frequency response corrections for eddy-correlation systems, Bound.-Lay. Meteorol., 37(1-2), 17-35, 1986.

Nakai, T., van der Molen, M. K., Gash, J. H. C., et al.: Correction of sonic anemometer angle of attack errors, Agr. Forest Meteorol., 136(1-2), 19-30, 2006.

Nelson, D. D., McManus, B., Urbanski, S., et al.: High precision measurements of atmospheric nitrous oxide and methane using thermoelectrically cooled mid-infrared quantum cascade lasers and detectors, Spectrochimica Acta Part a-Molecular and Biomolecular Spectroscopy, 60(14), 3325-3335, 2004.

O'Keefe, A.: Integrated cavity output analysis of ultra-weak absorption, Chemi. Phys. Lett., 293(5-6), 331-336, 1998.

Pattey, E., Desjardins, R. L., and Rochette, P.: Accuracy of the Relaxed Eddy-Accumulation Technique, Evaluated Using $\mathrm{CO}_{2}$ Flux Measurements, Bound.-Lay. Meteorol., 66(4), 341-355, 1993.

Rinne, H. J. I., Delany, A. C., Greenberg, J. P., et al.: A true eddy accumulation system for trace gas fluxes using disjunct eddy sampling method, J. Geophys. Res.-Atmos., 105(D20), $24791-$ 24 798, 2000.

Rinne, H. J. I., Guenther, A. B., Warneke, C., et al.: Disjunct eddy covariance technique for trace gas flux measurements, Geophys. Res. Lett., 28(16), 3139-3142, 2001.

Smeets, C. J. P. P., Duynkerke, P. G., and Vugts, H. F.: Turbulence characteristics of the stable boundary layer over a mid-latitude 
glacier. Part I: A combination of katabatic and large-scale forcing, Bound.-Lay. Meteorol., 87(1), 117-145, 1998.

Stull, R. B.: An Introduction to boundary layer meteorology, Dordrecht, Kluwer Academic Publishers, Atmospheric Sciences Library, Chapter 8, 1988.

Van der Molen, M. K.: Meteorological impacts of land use change in the Maritime tropics, Chapter 3, Data analysis, Thesis, Vrije Universiteit, 35-72, 2002.

Van der Molen, M. K., Gash, J. H. C., Elbers, J. A., et al.: Sonic anemometer (co)sine response and flux measurement - II. The effect of introducing an angle of attack dependent calibration, Agr. Forest Meteorol., 122(1-2), 95-109, 2004.

Van der Molen, M. K., Zeeman, M. J., Lebis, J., et al.: EClog: A handheld eddy covariance logging system, Comput. Electron. Agr., 51(1-2), 110-114, 2006.

Verma, S. B., Ullman, F. G., Billesbach, D., et al.: Eddy correlation measurements of methane flux in a northern peatland ecosystem. Bound.-Lay. Meteorol., 58, 289-304, 1992.
Werle, P., Mucke, R., and Slemr, F.: The Limits of Signal Averaging in Atmospheric Trace-Gas Monitoring by Tunable Diode-Laser Absorption-Spectroscopy (Tdlas), Appl. Phys. B-Photo., 57(2), 131-139, 1993.

Wohlfahrt, G., Anfang, C., Bahn, M., et al.: Quantifying nighttime ecosystem respiration of a meadow using eddy covariance, chambers and modelling, Agr. Forest Meteorol., 128(3-4), 141$162,2005$.

Zahniser, M. S., Nelson, D. D., McManus, J. B., et al.: Measurement of Trace Gas Fluxes Using Tunable Diode-Laser Spectroscopy, Philosophical Transactions of the Royal Society of London Series a-Mathematical Physical and Engineering Sciences, 351(1696), 371-381, 1995. 